DOI: 10.14526/2070-4798-2020-15-1-169-175

\title{
Functional interaction between cardiovascular and respiratory systems during testing loads
}

\author{
Yuriy S. Vanyushin ${ }^{1 *}$, Nikolay A. Fedorov', Natalya O. Kuznetsova ${ }^{2}$ \\ ${ }^{1}$ Kazan State Agrarian University \\ Kazan, Russia \\ ORCID: oooo-Ooo3-2667-6124, kaf.fv.kgau@mail.ru* \\ ORCID: oooo-ooo2-6515-0451,nik-f-84@mail.ru \\ ${ }^{2} M$. Akmulla State Pedagogical University \\ Ufa, Russia \\ ORCID: oooo-ooo3-3995-4269,kaf.fv.kgau@mail.ru
}

\begin{abstract}
Modern scientific research works in the sphere of physiology are mostly oriented towards studying difficult signals. They are formed as a result of interaction between the indices of one functional system or between different physiological systems. Such interconnection leads to the processes, which form the base for varied physiological functions of an organism. It provides organism integrity, an effective adaptive reaction formation to external stimuli. They include physical load of dynamic and static character. One of such systems is cardiorespiratory system, the signals of which are formed as a result of interaction between varied elements of cardiovascular and respiratory systems. Materials. Functional interaction of cardiovascular and respiratory systems study during testing loads and dominating factors revelation during adaptation to these loads. Research methods. Information sources analysis and summarizing, volume and differential rheograms registration, electrocardiograms, external respiration and gas exchange indices determination during physical load of the increasing power at bicycle ergometer, methods of mathematical statistics. Results. The complex character of our research works provided compensatory reactions of cardiac output revelation during active body position change. As a result we revealed chronotropic, inotropic, vascular and respiratory compensatory reactions of cardiac output. One of the ways of sports results improvement, especially in the kinds of sport, connected with endurance development, is functional abilities of cardiorespiratory system broadening. It depends on the age of the athletes. Conclusion. The processes of adaptation and functional interaction change between cardiovascular and respiratory systems during testing loads depends on different physiological orientation of these loads. The revealed physiological peculiarities of oxygen provision help to solve the problems connected with motor qualities upbringing and development during educational-training process of athletes.
\end{abstract}

Keywords: adaptation, cardiorespiratory system, load, functional system, blood circulation, respiration.

For citation: Yuriy S. Vanyushin*, Nikolay A. Fedorov, Natalya O. Kuznetsova. Functional interaction between cardiovascular and respiratory systems during testing loads. Russian journal of Physical Education and Sport. 2020; 15(1): 135-140. DOI: 10.14526/2070-4798-2020-15-1-169-175

\section{INTRODUCTION}

Abbreviations:

respiration rate - R.R., breathing apparatus

- B.A., oxygen utilization - O.U., arterio - venous oxygen difference ${ }_{2}-\mathrm{AVOD}_{2}$, minute volume of respiration - MVR, maximum oxygen consumption - MOC.

Modern scientific research works in the sphere of physiology are mostly oriented towards studying difficult signals. They are formed as a result of interaction between the indices of one functional system or between different physiological systems
$[1,5,10]$.

Such interconnection leads to the processes, which form the base for varied physiological functions of an organism. It provides organism integrity, an effective adaptive reaction formation to external stimuli. They include physical load of dynamic and static character.

One of such systems is cardiorespiratory system, the signals of which are formed as a result of interaction between varied elements of cardiovascular and respiratory systems. That is why cardiorespiratory system study in all its variants is 
still an important problem of physiology, in spite of the fact that more than 50 years passed since the firs work was published (E.D. Adrian et al, 1932). Cardiorespiratory system is the result of a long-term interaction between cardiovascular and respiratory systems [3, 7, 11, 12]. Central interactions of these systems are realized by an independent system of neurons. It reacts to the signals with the receptors of lungs retraction, vessels and heart. The main role of these neurons is in the objectives of respiration and blood circulation combination into one function. It provides constant functions of an organism support, in particular, gas exchange of the organism [2].

The aim of the research is to study functional interaction between cardiovascular and respiratory systems during testing loads of different physiological orientation and power and also dominant factors revelation during adaptation to these loads.

\section{RESEARCH METHODS}

The research work was held in the laboratory of "Physical Education" department functional diagnostics at Kazan State Agrarian University. 105 male respondents took part in the research (18-35 years-old).We simultaneously registered volume and differential rheograms, electrocardiograms, defined the indices of external respiration and gas exchange during physical load of the increasing power at bicycle ergometer.

\section{RESULTS AND DISCUSSION}

One of the important parameters, which provides oxygen, is maximum oxygen consumption (MOC). It is considered that the need of the tissues for oxygen is the main factor. It controls and regulates the volume of cardiac output. In physiology there is a well-known fact of MOC decrease during an active transfer of the respondents from the lying position to standing one. In this case heart rate and peripheral resistance of vessels reflexly increase. However, not often they are able to compensate considerable changes in impact blowout.

Respiratory system also takes part in MOC compensation during transfer of the respondents from the lying position to standing and sitting position. This is proved by the increase of minute volume of respiration (MVR) and the depth of respiration. They increase in sitting and standing position. Moreover, the conditions are created for the increased oxygen use by the tissues of the organism. This is also proved by the values of arterio-venous oxygen difference2 (AVOD2) which increased in sitting and standing position in comparison with horizontal body position. Such kind of shift in gas exchange is a compensatory reaction during cardiac output decrease.

The complex character of our research works provided compensatory reactions of cardiac output revelation during an active body position change. As a result we defined chronotropic, inotropic, vascular and respiratory compensatory reactions of cardiac output.

In accordance with modern notions, oxygen provision in an organism is realized by the degree of oxygen regulation system development and an optimal interaction between different parts of this system. It includes external respiration, blood circulation and gas exchange. That is why one of the ways to increase sports results, especially in kinds of sport, connected with endurance development, is functional abilities of cardiorespiratory system broadening. This, as our results showed, depends on the age of those, who train.

The most effective mechanism in providing oxygen is considered to be cardiac output increase. However, the results, received by us [4, 8, 9], prove MOC decrease during the transfer from one load to another. In this connection we can suppose that there are other mechanisms. They are directed toward oxygen needs satisfaction of an organism during muscle activity. One of them is external respiration. It is considered by some scientists [6] the factor, which limits the ability to achieve high sports results.

At the level of respiration system adaptation is characterized by maximal mobilization of external respiration. It is demonstrated by the increase of lung ventilation, as a result of respiration depth and frequency increase. The greatest values of lung ventilation we registered in the groups of $15-16$ year-old teen-agers and adults athletes at the age of 36-6o (table 1). It is obvious that the mechanism, connected with external respiration increase during 
the load fulfillment at bicycle ergometer in these groups is the leading one and physical working capacity is provided by considerable tension of cardiorespiratory system. In the group of teen-agers it happens owing to respiration frequency increase. This factor can be explained from the point of view of age-related characteristics of an organism development, as by the age of 16 morpho-functional formation of respiration system finishes and the training process orientation should be directed toward respiration system potential development. It would provide organism aerobic productivity increase.

Table 1 - The indices of external respiration in the groups of teen-agers (1), young men (2) and adults athletes $(3,4)$ during the increasing power load

\begin{tabular}{|c|c|c|c|c|c|}
\hline \multirow{2}{*}{ Load } & \multirow{2}{*}{ Indices } & \multicolumn{4}{|c|}{ Groups of athletes } \\
\hline & & 1 & 2 & 3 & 4 \\
\hline \multirow{3}{*}{ Initial state } & R.R, res/min & $18,09 \pm 1,28$ & $17,04 \pm 0,59$ & $15,12 \pm 0,48$ & $13,75 \pm 0,68^{\mathrm{vx}}$ \\
\hline & B.A., ml & $0,56 \pm 0,05$ & $0,61 \pm 0,03$ & $0,64 \pm 0,04$ & $0,76 \pm 0,04^{\mathrm{vx}}$ \\
\hline & MVR, l/min & $9,73 \pm 0,81$ & $10,24 \pm 0,40$ & $9,59 \pm 0,61$ & $10,15 \pm 0,47$ \\
\hline \multirow{3}{*}{$50 \mathrm{~W}$} & R.R., res/min & $22,81 \pm 1,82$ & $20,80 \pm 0,86$ & $19,04 \pm 0,82$ & $19,42 \pm 0,51$ \\
\hline & B.A, ml & $1,17 \pm 0,08$ & $1,12 \pm 0,04$ & $1,24 \pm 0,04$ & $1,41 \pm 0,05^{\mathrm{vx}}$ \\
\hline & MVR, $1 / \min$ & $25,76 \pm 1,74$ & $22,85 \pm 0,87$ & $23,41 \pm 1,00$ & $27,25 \pm 1,01^{x}$ \\
\hline \multirow{3}{*}{$100 \mathrm{~W}$} & R.R., res/min & $26,09 \pm 2,02$ & $22,35 \pm 0,99$ & $20,02 \pm 0,75^{*}$ & $19,04 \pm 1,17^{\mathrm{vx}}$ \\
\hline & B.A., ml & $1,58 \pm 0,09$ & $1,56 \pm 0,06$ & $1,67 \pm 0,05$ & $1,93 \pm 0,07^{\mathrm{vx}}$ \\
\hline & MVR, l/min & $40,35 \pm 3,04$ & $33,11 \pm 1,27^{+}$ & $33,50 \pm 1,44^{*}$ & $37,87 \pm 0,89^{x \cdot}$ \\
\hline \multirow[b]{3}{*}{$150 \mathrm{~W}$} & R.R., res/min & $30,19 \pm 1,78$ & $25,00 \pm 0,94^{+}$ & $21,47 \pm 1,00^{* 0}$ & $23,83 \pm 0,89^{v}$ \\
\hline & B.A., ml & $1,83 \pm 0,10$ & $1,88 \pm 0,07$ & $2,20 \pm 0,08^{* 0}$ & $2,42 \pm 0,11^{\mathrm{vx}}$ \\
\hline & MVR, l/min & $54,15 \pm 3,21$ & $45,96 \pm 1,28^{+}$ & $46,49 \pm 1,60^{*}$ & $56,55^{ \pm 2,15^{\mathrm{x}}}$ \\
\hline \multirow[b]{3}{*}{$200 \mathrm{~W}$} & R.R., res/min & $33,00 \pm 2,28$ & $27,46 \pm 0,85^{+}$ & $24,35 \pm 1,13^{* 0}$ & $27,78 \pm 1,08^{\mathrm{v}}$ \\
\hline & B.A., ml & $2,13 \pm 0,11$ & $2,20 \pm 0,07$ & $2,49 \pm 0,09^{* 0}$ & $2,77 \pm 0,12^{v x}$ \\
\hline & MVR, l/min & $68,57 \pm 3,84$ & $59,34 \pm 1,48^{+}$ & $59,55 \pm 1,79^{*}$ & $75,65 \pm 3,26^{x}$ \\
\hline
\end{tabular}

Notes:

+ - statistical validity of differences between groups 1 and 2

* - statistical validity of differences between groups 1 and 3

$\mathrm{v}$ - statistical validity of differences between groups 1 and 4

0 - statistical validity of differences between groups 2 and 3

$\mathrm{x}$ - statistical validity of differences between groups 2 and 4

- - statistical validity of differences between groups 3 and 4 
It should be mentioned that received by us results of lung ventilation don't form the criterion of sufficiently high training level. In this case oxygen and energetic value of respiration increases. In these conditions adaptation to physical loads is better realized by means of effectiveness increase of oxygen transportation and utilization system. It is proved by validly high values of blood circulation index and cardiac index in the group of boys at the age of 17-21 (table 2). Moreover, the values of oxygen utilization2 (OU2) also increase in the group of adults athletes at the age of 22-35 in terms of the same oxygen consumption during the load of the increasing power fulfillment. Thus, with the mass of mitochondria increase in skeletal muscles considerable aerobic power of an organism increase is achieved and the ability of the respiration center to support excitation increases.

\section{CONCLUSION}

Thus, the processes of adaptation and functionalinteractionchangebetweencardiovascular and respiratory systems during testing loads depends on different physiological orientation of these loads. The revealed physiological peculiarities of oxygen provision help to solve the problems connected with motor qualities upbringing and development during educational-training process of athletes.

\section{REFERENCES}

1. Agadzhanyan N.A., Ruzhenkova I.V., Starshinov Yu.P. The peculiarities of adaptation of cardiovascular system of a young organism. Fiziologiya cheloveka. 1997; 23(1): 93-104 [In Russ.].

2. Agadzhanyan N.A., Baevskiy R.M., Berseneva A.P. Problemy adaptacii I uchenie o zdorov'e [Problems of adaptation and theory of health]. Moscow: Russian University of Nations Friendship publishing house. 2006: 284 [In Russ.].

3. Anokhin P.K. Principial'nye voprosy obchej teorii funkcional'nyh sistem [Principle questions of general theory of functional systems]. Moscow: Medicine. 1980 [In Russ.].

4. Vanyushin Yu.S., Sitdikov F.G. Cardiac activity of teen-agers adaptation to the increasing power load. Fiziologiya cheloveka. 2001; 27(2): 9197 [In Russ.].

5. Vanyushin Yu.S., Khayrullin R.R., Elistratov D.E. Morfofunkcional'nye osobennosti rastuchego organizma [Morphofunctiona peculiarities of a growing organism]. Kazan: Kazan State Agrarian University publishing house. 2019:120 [In Russ.].

6. Kuchkin S.N. Reserves of respiration system and aerobic productivity of an organism. Doctor's thesis. Kazan. 1986: 48.

7. Sudakov K.V. Fiziologiya. Osnovy I funkcional'ny sistemy: kurs lekcij [Physiology. The basis and functional systems: course of lectures]. Moscow: Medicine. 2000: 784 [In Russ.].

8. Vanyshin Y.S., Khairullin R.R., Elistratov D.E., Tazieva Z.N. Value of Testing Loads in Determining the Functional State of the Athletes Body. International Journal of Computational Intelligence Systems. 808-810.

9. Vanyshin Y.S., Khairullin R.R., Elistratov D.E., Fedorov N.A. Cardiac Output and its Components Among Young Athletes During Functional Loads. International Journal of Computational Intelligence Systems. 756-758.

10. Brennan M., Palaniswami M., Kamen P. Poincare plot interpretation using a physiological model of HRV based on a network of oscillators. Am J Physiol Heart Circ Physiol. 2002; 238(5): H1873-H1886.

11. Taylor E.W., Jordan D., Coote J.H. Central Control of the Cardiovascular and Respiratory Systems and Their Interactions in Vertebrates. Physiological Reviews. 1999; 79(3): 855-916.

12. Fedorov N.A., Vanyushin Yu.S., Elistratov D.E. The influence of blood circulation typological features on the cardiorespiratory system indicators under increasing load. Pedagogiko-psihologicheskie I medico-biologicheskie probemy fizicheskoj kul'tury I sporta $=$ The Russian journal of Physical Education and Sport. 2018; 13(3): 199-206. DOI: 10.14526/2070-4798-2018-13-3-199-206 [In Russ., In Engl.]. 


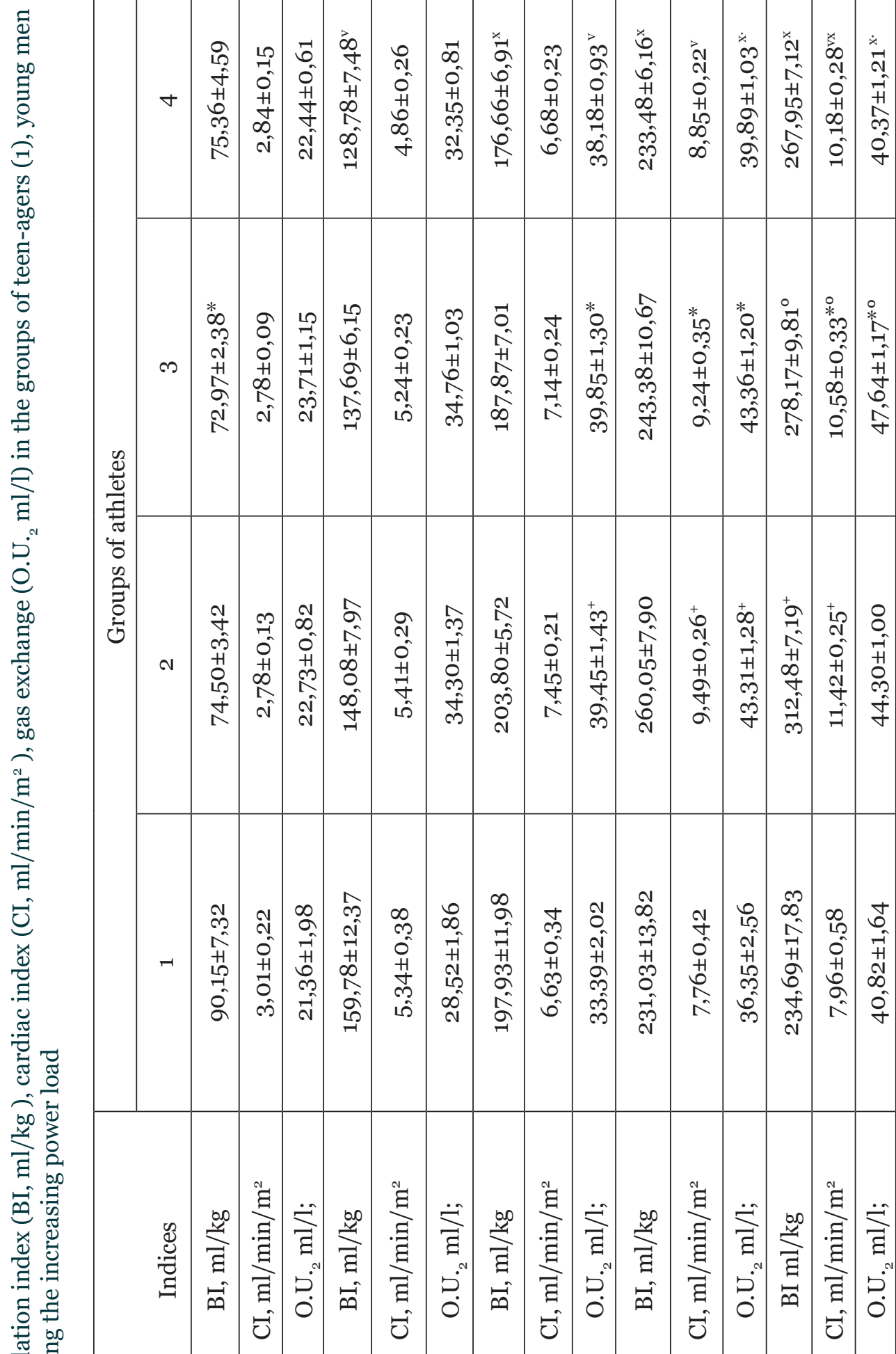

吕

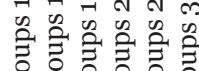

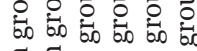

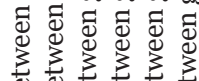

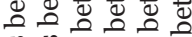

ت.

ช

\begin{tabular}{|l|l|l|l|l|l|l|l|l|l|l|l|}
\hline & & & & & & & & & & & \\
\hline
\end{tabular}

造

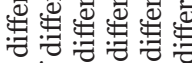

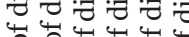

पै

就

䒕

్ָర్ర



3

3
3
0
0

3

3
3
8

(⿸丆口广

N

을

ส

in

จำ

8 象

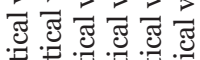




\section{Submitted: 15.02.2020}

\section{Author's information:}

Yuriy S. Vanyushin - Doctor of Biological Sciences, Professor, Kazan State Agrarian University, 420015, Russia, Kazan, K. Marks str., House 65, e-mail: kaf.fu.kgau@mail.ru

Nikolay A. Fedorov - Candidate of Biological Sciences, Associate Professor, Kazan State Agrarian University, 420015, Russia, Kazan, K. Marks str., House 65, e-mail: nik-f-84@mail.ru

Natalya O. Kuznetsova - Candidate of Biological Sciences, Associate Professor, M. Akmulla State Pedagogical University, 450oo8, Russia, Ufa, Oktyabrskoy revolutsii str., House 3-a, e-mail: kaf. fv.kgau@mail.ru 